\title{
Faktor-Faktor Yang Mempengaruhi Minat Berwirausaha (Studi Kasus Mahasiswa Program Studi Pendidikan Ekonomi STKIP Pembangunan Indonesia)
}

\author{
Harti Oktarina $^{1 *}$, Eka Adnan Agung ${ }^{2}$, Sitti Hajar Aswad ${ }^{3}$ \\ ${ }^{123}$ STKIP Pembangunan Indonesia/Pendidikan Ekonomi/Pascasarjana Universitas Negeri Makassar \\ 1*Email: hartioktarina@gmail.com ,2Email: ekaadnan.agung@gmail.com, \\ ${ }^{3}$ Email: sittihajaraswad90@gmail.com \\ ${ }^{*}$ Corresponding author
}

\begin{abstract}
The aim of this research is to know: 1) The effect of Entrepreneurship Education on Entrepreneurial Interest in STKIP Pembangunan Indonesia economic education students, 2) the effect of Earning Expectations on Entrepreneurial Interest in STKIP Pembangunan Indonesia economic education students, 3) The effect of Family Environment on Entrepreneurship Interest in Economic Education students STKIP Pembangunan Indonesia, and 4) The Effect of Entrepreneurship Education, Earning Expectations, and Family Environment on Entrepreneurial Interest in STKIP Pembangunan Indonesia economic education students. This research was causal comparative research. The population in this research are students of economic education who had participated in entrepreneurship courses with a sample of 194 students. Methods of data collection in this research using questionnaire. The instrument test was do to 30 students of economic education STKIP Pembangunan Indonesia. Classic assumption test includes normality test, autocorrelation test, multicollinearity test, and heteroscedasticity test. The hypothesis test used is multiple regression analysis. The simultaneous test results showed that Entrepreneurship Education, Earning Expectations and Family Environment had an effect on Entrepreneurial Interest in STKIP Pembangunan Indonesia economic education students.
\end{abstract}

Keywords: Entrepreneurship Education; Earnings Expectations; Family

Environment; Interest in Entrepreneurship

\begin{abstract}
Abstrak. Penelitian ini bertujuan untuk mengetahui: 1) Pengaruh Pendidikan Kewirausahaan terhadap Minat Berwirausaha pada mahasiswa pendidikan ekonomi STKIP Pembangunan Indonesia, 2) Pengaruh Ekspektasi Pendapatan terhadap Minat Berwirausaha pada mahasiswa pendidikan ekonomi STKIP Pembangunan Indonesia, 3) Pengaruh Lingkungan Keluarga terhadap Minat Berwirausaha pada mahasiswa pendidikan ekonomi STKIP Pembangunan Indonesia, dan 4) Pengaruh Pendidikan Kewirausahaan, Ekspektasi Pendapatan, dan Lingkungan Keluarga terhadap Minat Berwirausaha mahasiswa pendidikan ekonomi STKIP Pembangunan Indonesia. Penelitian ini termasuk penelitian kausal komparatif. Populasi penelitian ini adalah mahasiswa Pendidikan Ekonomi STKIP Pembangunan Indonesia yang telah mengikuti mata kuliah kewirausahaan dengan sampel sebanyak 194 mahasiswa. Metode pengumpulan data dalam penelitian ini adalah menggunakan angket atau kuesioner. Pengujian instrumen dilakukan kepada mahasiswa pendidikan ekonomi STKIP Pembangunan Indonesia sebanyak 30 mahasiswa. Uji asumsi klasik meliputi uji normalitas, uji autokorelasi, uji multikolinearitas, dan uji heteroskedastisitas. Uji hipotesis yang digunakan adalah analisis regresi berganda. Hasil uji simultan menunjukkan bahwa Pendidikan Kewirausahaan, Ekspektasi Pendapatan dan Lingkungan Keluarga berpengaruh terhadap Minat Berwirausaha mahasiswa pendidikan ekonomi STKIP Pembangunan Indonesia.
\end{abstract}

Kata kunci: Pendidikan Kewirausahaan; Ekspektasi Pendapatan; Lingkungan Keluarga; Minat Berwirausaha 


\section{PENDAHULUAN}

Memasuki persaingan global saat ini, masalah pengangguran merupakan masalah klasik yang dialami negara-negara berkembang termasuk Indonesia. Pengangguran itu bukanlah hasil sebuah pilihan untuk tidak bekerja, melainkan akibat dari semakin sulitnya mendapatkan pekerjaan, terutama di kota-kota besar. Kondisi yang dihadapi ini akan semakin diperburuk jika setiap individu hanya berorientasi sebagai pencari kerja (job seeker) bukan menjadi pencipta pekerjaan (job creator). Jika dibandingkan dengan negara-negara lain, perkembangan kewirausahaan di Indonesia masih sangat kurang yaitu 3\%. Sebagai pembanding, kewirausahaan di Amerika Serikat tercatat mencapai $12 \%$ dari total penduduknya, China sebanyak $10 \%$, Singapura sebanyak $7 \%$, dan Malaysia sebanyak 5\%.

Menumbuhkan jiwa kewirausahaan para mahasiswa perguruan tinggi bisa menjadi alternatif untuk mengurangi tingkat pengangguran, karena dengan memiliki jiwa kewirausahaan diharapkan mahasiswa dapat menciptakan pekerjaan atau berwirausaha setelah lulus dari perguruan tinggi. Zimmerer, Scarborough dan Wilson (2008: 20), menyatakan bahwa salah satu faktor pendorong pertumbuhan kewirausahaan disuatu negara terletak pada peranan universitas melalui penyelenggaraan pendidikan kewirausahaan baik dalam kegiatan perkuliahan maupun kegiatan seminar dan praktik kewirausahaan. Pihak universitas bertanggung jawab dalam mendidik dan memberikan kemampuan wirausaha kepada para lulusannya dan memberikan motivasi untuk berani memilih berwirausaha sebagai karir mereka.

Seseorang yang telah menerima Pendidikan Kewirausahaan akan memiliki ilmu berwirausaha sehingga dengan pemahaman ilmu tersebut akan berpengaruh terhadap minat berwirausaha. Pengetahuan yang didapat selama perkuliahan tertutama mata kuliah kewirausahaan yang berupa teori dan praktik dapat menjadi bekal untuk berwirausaha dan dapat dijadikan bahan pertimbangan mahasiswa untuk menentukan masa depan

Ekspektasi pendapatan adalah harapan seseorang akan pendapatan yang diperolehnya dari kegiatan usaha ataupun bekerja. Seseorang dengan ekspektasi pendapatan yang lebih tinggi daripada bekerja menjadi karyawan merupakan daya tarik untuk menjadi wirausaha.
Berdasarkan hasil observasi awal, masih banyak mahasiswa yang beranggapan bahwa pendapatan dari berwirausaha tersebut masih rendah dan tidak menentu padahal tinggi rendahnya pendapatan yang diperoleh dari berwirausaha tergantung usaha yang dilakukan seseorang dalam mewujudkan pendapatan yang tinggi.

Lingkungan keluarga adalah lingkungan pertama seseorang dalam kehidupanya. Menjadi seorang wirausaha tidak lepas dari dukungan orang tua atau keluarganya, apabila keluarga memberi dukungan serta pengaruh positif terhadap minat berwirausaha maka seseorang akan memiliki minat berwirausaha, begitupun sebaliknya. Berdasarkan observasi awal peneliti, kebanyakan orang tua menginginkan anaknya untuk menjadi PNS.

Program studi Pendidikan Ekonomi STKIP Pembangunan Indonesia dalam kurikulumnya telah memasukkan mata kuliah kewirausahaan. Dalam kegiatan perkuliahan, telah diberikan teori-teori kewirausahaan serta praktik kewirausahaan. Tujuannya agar mendorong mahasiswa untuk menjadi wirausaha setelah mereka lulus sehingga jumlah wirausaha di Indonesia bertambah dan dapat mengurangi angka pengangguran. Berdasarkan observasi awal peneliti, masih sedikit mahasiswa yang memilih profesi berwirausaha karena pengetahuan mereka tentang berwirausaha masih kurang serta tidak menguasai bidang tersebut. Kebanyakan mahasiswa memilih profesi sebagai guru karena sesuai jurusan mereka serta menjadi PNS karena dukungan orang tua.

Berangkat dari permasalahan tersebut penulis bermaksud menggali lebih dalam mengenai faktor-faktor yang mempengaruhi minat berwirausaha Mahasiswa Program Studi Pendidikan Ekonomi STKIP Pembangunan Indonesia.

\section{METODE PENELITIAN}

Jenis penelitian yang digunakan dalam penelitian ini adalah penelitian kausal komparatif. Pendekatan yang digunakan dalam penelitian ini adalah pendekatan kuantitatif karena data yang disajikan berhubungan dengan angka. Dalam penelitian ini terdapat satu variabel dependen (Y) yaitu minat berwirausaha. Indikator yang digunakan antara lain, tidak ada ketergantungan pada orang lain, dapat membantu lingkungan sosial, senang jika 
menjadi seorang wirausaha dan berorientasi pada masa depan. Selain itu, terdapat tiga variabel independen yaitu Pendidikan Kewirausahaan (X1) Indikator yang digunakan adalah pemahaman materi yang diajarkan dan penerapan dari teori mata kuliah yang diajarkan. Eskpektasi Pendapatan (X2) Indikator yang digunakan adalah pendapatan yang tinggi dan pendapatan tidak terbatas dan Lingkungan Keluarga (X3) Indikator yang digunakan adalah dukungan orang tua, dan pekerjaan orang tua.

Populasi dari penelitian ini adalah mahasiswa Program Studi Pendidikan Ekonomi STKIP Pembangunan Indonesia semester ganjil (tujuh) tahun akademik 2015/2016 sebanyak 374 orang. Teknik sampling yang digunakan adalah teknik purposive random sampling, yaitu pengambilan sampel dengan kriteria atau syarat tertentu (Sugiyono, 2008). Adapun kriterianya adalah:

a. Mahasiswa yang sudah mengambil mata kuliah Kewirausahaan.

b. Mahasiswa aktif.

Penentuan jumlah responden yang akan dibagikan kuesioner dengan menggunakan rumus Slovin, yaitu:

$$
n=\frac{\mathrm{N}}{1+\mathrm{N} e^{2}}
$$

Keterangan: $n=$ Jumlah sampel

$\mathrm{N}=$ Jumlah Populasi

$e=$ Batas toleransi kesalahan (error)

Maka jumlah sampel dengan perhitungan sebagai berikut:

$n=\frac{374}{1+(374)\left(0,05^{2}\right)}=193,28$ dibulatkan menjadi 194

Metode pengumpulan data adalah menggunakan kuesioner yang disebarkan langsung kepada responden yaitu mahasiswa program studi pendidikan ekonomi STKIP Pembangunan Indonesia. Dalam pengumpulan data, peneliti menggunakan skala likert dengan beberapa kategori yaitu "Sangat Setuju" (SS), "Setuju" (S), "Tidak Setuju" (TS) dan "Sangat Tidak Setuju" (STS). Skala likert guna mengukur variabel Minat Berwirausaha, Ekspektasi Pendapatan, Motivasi, Pendidikan Kewirausahaan, dan Norma Subjektif.

a. Uji Asumsi Klasik

1) Uji Normalitas
Uji normalitas digunakan dengan metode Kolmogorof Smirnov. Pengambilan keputusannya adalah jika Sig.>0,05 maka Ho diterima artinya variabel terdistribusi normal.

2) Uji Autokorelasi

Uji autokorelasi digunakan untuk mengetahui ada atau tidaknya penyimpangan asumsi klasik autokorelasi yaitu korelasi yang terjadi antara residual pada satu pengamatan dengan pengamatan lain pada model regresi. Prasyarat yang harus terpenuhi adalah tidak adanya autokorelasi dalam model regresi. Metode pengujian yang sering digunakan adalah dengan uji Durbin-Watson (uji DW) dengan ketentuan sebagai berikut:

- Jika d lebih kecil dari dL atau lebih besar dari (4-dL) maka hopotesis nol ditolak, yang berarti terdapat autokorelasi.

- Jika d terletak antara dU dan (4-dU), maka hipotesis nol diterima, yang berarti tidak ada autokorelasi.

- Jika d terletak antara dL dan dU atau diantara (4-dU) dan (4-dL), maka tidak menghasilkan kesimpulan yang pastiya, maka dinyatakan terdapat autokorelasi.

3) Uji Multikolinieritas

Model regresi yang baik tidak terdapat korelasi antarvariabel independen. Apabila nilai tolerance lebih 0,10 atau nilai VIF kurang dari 10 maka menunjukkan tidak terjadi adanya multikolinearitas antarvariabel.

4) Uji Heteroskedastisitas

Untuk mengetahui terjadinya heteroskedastisitas menggunakan Uji Glejser. Apabila nilai signifikansi masingmasing variabel independen lebih besar dari 0,05 maka model regresi tersebut adalah tidak terjadi heteroskedastisitas.

\section{b. Regresi Linier Berganda}

Model persamaan regresi terdapat pada variabel minat berwirausaha $(\mathrm{Y})$, pendidikan kewirausahaan $\left(\mathrm{X}_{1}\right)$, ekspektasi pendapatan $\left(\mathrm{X}_{2}\right)$, dan lingkungan keluarga $\left(\mathrm{X}_{3}\right)$. Adapun model penelitiannya sebagai berikut:

$\mathbf{Y}=\mathbf{a}+\mathbf{b X _ { 1 }}+\mathbf{b X _ { 2 }}+\mathbf{b X _ { 3 }}+\mathbf{e}$

Keterangan :

$\mathrm{Y}=$ Minat berwirausaha

$\mathrm{X}_{1}=$ Pendidikan Kewirausahaan 
$\mathrm{X}_{2}=$ Ekspektasi Pendapatan

$\mathrm{X}_{3}=$ Lingkungan Keluarga

c. Uji Simultan (Uji F)

Uji $F$ digunakan untuk mengetahui pengaruh variabel-variabel independen secara bersama-sama (simultan) terhadap variabel dependen. Pengambilan keputusannya adalah jika nilai signifikansi<0,05, maka Ha diterima dan Ho ditolak, begitupun sebaliknya.

a. Uji Parsial (Uji t)

Uji $t$ digunakan untuk menguji pengaruh antara variable independen terhadap variabel dependen secara terpisah (parsial). kriteria pengujian adalah jika signifikansi<0,05, maka Ho ditolak dan $\mathrm{Ha}$ diterima.

\section{HASIL DAN PEMBAHASAN \\ Hasil Analisis Data}

\section{Uji Normalitas}

Dalam penelitian ini uji normalitas menggunakan uji statistik nonparametrik Kolmogorov Smirnov. Data memiliki distribusi normal ketika nilai Asymp.Sig. lebih besar dari nilai alpha yang sudah ditentukan yaitu 0,05.dengan hasil sebagai berikut:

Tabel 1. Hasil Uji Normalitas

\begin{tabular}{lcc}
\hline \multicolumn{1}{c}{ Variabel } & Asymp. Sig. (2-tailed) & Kesimpulan \\
\hline Pendidikan kewirausahaan & $0,060>0,05$ & Normal \\
Ekspektasi pendapatan & $0,050>0,05$ & Normal \\
Lingkungan keluarga & $0,055>0,05$ & Normal \\
Minat wirausaha & $0,063>0,05$ & Normal \\
\hline
\end{tabular}

Sumber: Data primer yang diolah

Berdasarkan hasil uji normalitas dengan menggunakan uji statistik nonparametrik Kolmogorov Smirnov diperoleh nilai Asymp.Sig. untuk pendidikan kewirausahaan, ekspektasi pendapatan dan lingkungan keluarga masingmasing sebesar 0,060; 0,050; 0,055 lebih besar dari nilai alpha $(0,05)$ sehingga dapat dikatakan bahwa data keempat variabel tersebut terdistribusi secara normal.

\section{Uji autokorelasi}

Hasil Uji autokorelasi dapat dilihat pada tabel berikut:

Tabel 2 Hasil Uji Autokorelasi

\begin{tabular}{|c|c|c|c|c|c|}
\hline \multicolumn{6}{|c|}{ Model Summary } \\
\hline Model & $\mathrm{R}$ & R Square & Adjusted R Square & $\begin{array}{l}\text { Std. Error of the } \\
\text { Estimate }\end{array}$ & Durbin-Watson \\
\hline 1 & $.180^{\mathrm{a}}$ & .032 & .017 & 3.97298 & 1.93 \\
\hline
\end{tabular}

a. Predictors: (Constant), Lingkungan keluarga, Pendidikan Kewirausahaan,

Ekspektasi_Pendapatan

b. Dependent Variable: Minat_wirausaha

Berdasarkan hasil output diatas diperoleh nilai DW sebesar 1,933. Berdasarkan tabel DW dengan signifikasi 0,05 dan jumlah data (n) 193, serta $\mathrm{k}=3$ ( $\mathrm{k}$ adalah jumlah variabel independen) diperoleh nilai $\mathrm{dL}$ sebesar 1,7337 dan dU sebesar 1,7965. Berdasarkan hal tersebut maka nilai DW terletak diantara nilai
dU $(1,7965)$ dan 4-dU $(2,2035)$ yang berarti tidak ada autokorelasi.

\section{Uji multikolinieritas}

Model regresi yang baik tidak terdapat korelasi antarvariabel independen. Apabila nilai tolerance lebih 0,10 atau nilai VIF kurang dari 10 maka menunjukkan tidak terjadi adanya multikolinearitas antarvariabel.

Tabel 4.3 Hasil Uji Multikolinieritas

\begin{tabular}{lccc}
\hline \multicolumn{1}{c}{ Variabel } & \multicolumn{2}{c}{ Collinearity Statistics } & \multirow{2}{*}{ Kesimpulan } \\
& Tolerance & VIF & Tidak terjadi multikolinieritas \\
Pendidikan kewirausahaan & 0,986 & 1,014 & Tidak terjadi multikolinieritas \\
Ekspektasi pendapatan & 0,983 & 1,017 & Tidak terjadi multikolinieritas \\
Lingkungan keluarga & 0,987 & 1,013 &
\end{tabular}

Sumber: Data primer yang diolah 
Hasil pada tabel dapat dilihat bahwa variabel independen yaitu Pendidikan Kewirausahaan, Ekspektasi Pendapatan, dan Lingkungan Keluarga memiliki nilai VIF lebih kecil dari 10 dan nilai tolerance lebih besar dari 0,10 sehingga dapat disimpulkan tidak terjadi multikolinearitas antarvariabel.

\section{Uji Heteroskedastisitas}

Uji heteroskedastisitas digunakan untuk mengetahui apakah dalam model regresi terdapat ketidaksamaan varian dari residual satu pengamatan ke pengamatan yang lainnya. Menurut Imam $(2011,139)$ model regresi yang baik adalah homoskedastisitas atau tidak terjadi heteroskedastisitas. Untuk mengetahui terjadinya heteroskedastisitas menggunakan Uji Glejser. Apabila nilai signifikansi masingmasing variabel independen lebih besar dari 0,05 maka model regresi tersebut adalah homoskedastisitas atau tidak terjadi heteroskedastisitas. Berikut hasil uji heteroskedastisitas.

Tabel 4.4 Hasil Uji Heteroskedastisitas

\begin{tabular}{lcc}
\hline \multicolumn{1}{c}{ Variabel } & Nilai Signifikansi & Kesimpulan \\
\hline Pendidikan kewirausahaan & 0,051 & Tidak terjadi heteroskedastisitas \\
Ekspektasi pendapatan & 0,482 & Tidak terjadi heteroskedastisitas \\
Lingkungan keluarga & 0,400 & Tidak terjadi heteroskedastisitas \\
\hline
\end{tabular}

Sumber: Data primer yang diolah

Indikasi terjadi heteroskedastisitas jika nilai signifikansi variabel independen $<0,05$ (Ghozali, 2011: 143). Hasil uji glejser pada tabel menunjukkan nilai signifikansi seluruh variabel independen lebih dari 0,05 sehingga tidak terjadi heteroskedastisitas.

\section{Regresi Linier Berganda}

Model persamaan regresi terdapat pada variabel minat berwirausaha $(\mathrm{Y})$, pendidikan kewirausahaan $\left(\mathrm{X}_{1}\right)$, ekspektasi pendapatan $\left(\mathrm{X}_{2}\right)$, dan lingkungan keluarga $\left(\mathrm{X}_{3}\right)$. Adapun model penelitiannya sebagai berikut:

$Y=24,199+0,035 X_{1}+0,147 X_{2}+0,239 X_{3}+e$ Persamaan regresi tersebut menunjukkan bahwa:

- Jika tidak ada pendidikan kewirausahaan, ekspektasi pendapatan dan lingkungan keluarga maka minat berwirausaha mahasiswa pendidikan ekonomi hanya sebesar 24, 199

- Jika pendidikan kewiraushaan meningkat sebesar 1 satuan maka akan meningkatkan minat berwirausaha mahasiswa pendidikan ekonomi sebesar 0,035;

- Jika ekspektasi pendapatan meningkat sebesar 1 satuan maka akan meningkatkan minat berwirausaha mahasiswa pendidikan ekonomi sebesar 0,147;
- Jika lingkungan keluarga meningkat sebesar 1 satuan maka akan meningkatkan minat berwirausaha mahasiswa pendidikan ekonomi STKIP Pembangunan Indonesia sebesar 0,239.

\section{a. Pengujian Secara Simultan (Uji F)}

Uji simultan dengan $F$ test bertujuan untuk mengetahui pengaruh bersama-sama variabel independen terhadap variabel dependen. Berdasarkan uji anova (F) menunjukkan bahwa nilai signifikansi sebesar $0,03<0,05$ berarti variabel independen (pendidikan kewiraushaan, ekspektasi pendapatan, dan lingkungan keluarga) secara bersama-sama (simultan) berpengaruh signifikan terhadap minat berwirausaha mahasiswa pendidikan ekonomi STKIP Pembangunan Indonesia.

\section{b. Pengujian Secara Parsial (Uji T)}

Pengujian ini untuk mengetahui pengaruh masing-masing variabel independen terhadap variabel independen. Apabila nilai sig. $t$ kurang dari nilai alpha $(0,05)$ maka dapat disimpulkan variabel independen secara parsial berpengaruh terhadap variabel dependen. Dari hasil pengolahan data spss diperoleh nilai signifikansi t sebesar:

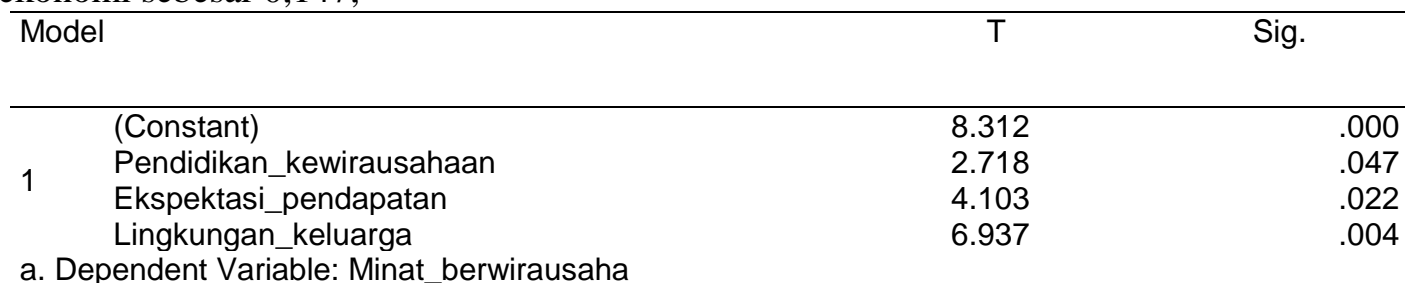

Sumber: Data diolah dengan SPSS 20 
1) Pendidikan Kewirausahaan

Berdasarkan hasil output spss diatas, diperoleh nilai signifikansi pendidikan kewirausahaan $<$ nilai alpha $(0,047<0,05)$ dengan nilai $\mathrm{t}$ hitung $>$ nilai $\mathrm{t}$ tabel $(2,718>$ 1,97253) maka dapat disimpulkan bahwa variabel pendidikan kewirausahaan berpengaruh secara signifikan terhadap minat berwirausaha mahasiswa pendidikan ekonomi STKIP Pembangunan Indonesia.

2) Ekspektasi Pendapatan

Berdasarkan hasil output spss diatas, diperoleh nilai signifikansi ekspektasi pendapatan $<$ nilai alpha $(0,022<0,05)$ dengan nilai $\mathrm{t}$ hitung $>$ nilai $\mathrm{t}$ tabel $(4,103>1,97253)$ maka dapat disimpulkan bahwa variabel ekspektasi pendapatan berpengaruh secara signifikan terhadap minat berwirausaha mahasiswa pendidikan ekonomi STKIP Pembangunan Indonesia.

3) Lingkungan Keluarga

Berdasarkan hasil output spss diatas, diperoleh nilai signifikansi < nilai alpha $(0,04<0,05)$ dengan nilai $t$ hitung $>$ nilai $t$ tabel $(6,937>1,97253)$ maka dapat disimpulkan bahwa variabel lingkungan keluarga berpengaruh secara signifikan terhadap minat berwirausaha mahasiswa pendidikan ekonomi STKIP Pembangunan Indonesia.

\section{Pembahasan}

1. Pengaruh Pendidikan Kewirausahaan, terhadap Minat Berwirausaha (Studi Kasus Mahasiswa Program Studi Pendidikan Ekonomi STKIP Pembangunan Indonesia)

Hasil penelitian mendukung hipotesis pertama yang menunjukkan bahwa variabel Pendidikan Kewrausahaan $\left(X_{1}\right)$ berpengaruh terhadap Minat Berwirausaha. Hasil analisis pada uji hipotesis pertama menghasilkan koefisien regresi $X_{1}$ sebesar 0,035 . Hal tersebut menujukkan bahwa setiap adanya peningkatan Pendidikan Kewirausahan sebesar 1 satuan akan meningkatkan Minat Berwirausaha Mahasiswa Pendidikan Ekonomi STKIP Pembangunan Indonesia sebesar 0,035 satuan. Variabel ini memiliki nilai $t$ hitung sebesar 2,718 serta memiliki nilai signifikansi sebesar 0,047 dimana nilai tersebut lebih kecil 0,05. Berdasarkan uraian tersebut dapat disimpulkan bahwa Pendidikan Kewirausahaan berpengaruh terhadap Minat Berwirausaha Mahasiswa Pendidikan Ekonomi STKIP Pembangunan Indonesia.

Pendidikan Kewirausahaaan yang diberikan kepada mahasiswa Pendidikan Ekonomi STKIP Pembangunan Indonesia melalui mata kuliah Kewirausahaan (Entrepreneurship) dan Praktek Wirausaha dapat menjadi modal dasar untuk berwirausaha. Pemahaman mataeri yang diajarkan dan penerapan dari teori mata kuliah yang dipelajari akan menjadikan mahasiswa semakin terampil dan muncul keyakinan untukmemulai suatu usaha.

Pendidikan kewirausahaan akan menanamkan nilai-nilai kewirausahaan yang nantinya akan membentuk pola pikir dan sikap mental berwirausaha sehingga seseorang akan memiliki minat berwirausaha. Pihak universitas memiliki tanggung jawab dalam memberikan keterampilan wirausaha kepada mahasiswa sehingga nantinya berani untuk memilih berkakir sebagai wirausaha. Hal tersebut sesuai dengan pernyataan Zimmerer, Scarborough, dan Wilson (2008: 20) yang mengatakan bahwa salah satu faktor pendorong pertumbuhan kerwirausahaan disuatu negara terletak pada peranan universitas melalui penyelenggaraan Pendidikan Kewirausahaan.

\section{Pengaruh Ekspektasi Pendapatan terhadap Minat Berwirausaha (Studi Kasus Mahasiswa Program Studi Pendidikan Ekonomi STKIP Pembangunan Indonesia)}

Hasil penelitian mendukung hipotesis kedua yang menunjukkan bahwa variabel Ekspektasi Pendapatan $\left(\mathrm{X}_{2}\right)$ berpengaruh terhadap Minat Berwirausaha. Hasil analsisi pada uji hipotesis kedua menghasilkan koefisien regresi $X_{2}$ sebesar 0,147. Hal tersebut menunjukkan bahwa setiap adanya peningkatan Ekspektasi Pendapatan sebesar 1 satuan akan meningkatkan Minat Berwirausaha Mahasiswa Pendidikan Ekonomi STKIP Pembangunan Indonesia sebesar 0,147 satuan. Variabel ini memiliki nilai hitung sebesar 4,103 serta nilai signifikansi sebesar 0,022 dimana nilai tersebut lebih kecil dari 0,05. Berdasarkan uraian tersebut dapat disimpulkan bahwa Ekspektasi Pendapatan berpengaruh terhadap Minat Berwirausaha Mahasiswa Pendidikan Ekonomi STKIP Pembangunan Indonesia. 
Ekspektasi pendapatan merupakan harapan seseorang untuk mendapatkan penghasilan berupa uang atau barang yang digunakan dalam pemenuhan kebutuhan hidup. Ekspektasi Pendapatan menjadi salah satu faktor yang dapat mempengaruhi Minat Berwirausaha. Seseorang yang berminat berwirausaha memiliki keinginan untuk menghasilkan pendapatan yang tidak terbatas dan melebihi karyawan. Meskipun demikian, besar atau kecilnya pendapatan yang diterima wirausaha bergantung pada seberapa keras usaha yang telah dilakukan. Ketika individu menginginkan penghasilan yang tinggi dari berwirausaha, maka hal tersebut dapat menjadi pendorong dalam meningkatkan minat berwirausaha.

\section{Pengaruh Lingkungan Keluarga terhadap Minat Berwirausaha (Studi Kasus Mahasiswa Program Studi Pendidikan Ekonomi STKIP Pembangunan Indonesia)}

Hasil penelitian mendukung hipotesis ketiga yang menunjukkan bahwa variabel Lingkungan Keluarga $\left(\mathrm{X}_{3}\right)$ berpengaruh terhadap Minat Berwirausaha. Hasil analsisi pada uji hipotesis ketiga menghasilkan koefisien regresi $X_{3}$ sebesar 0,239. Hal tersebut menunjukkan bahwa setiap adanya peningkatan Lingkungan Keluarga sebesar 1 satuan akan meningkatkan Minat Berwirausaha Mahasiswa Pendidikan Ekonomi STKIP Pembangunan Indonesia sebesar 0,239 satuan. Variabel ini memiliki nilai hitung sebesar 6,937 serta nilai signifikansi sebesar 0,004 dimana nilai tersebut lebih kecil dari 0,05. Berdasarkan uraian tersebut dapat disimpulkan bahwa Lingkungan Keluarga berpengaruh terhadap Minat Berwirausaha Mahasiswa Pendidikan Ekonomi STKIP Pembangunan Indonesia.

Hasil tersebut membuktikan bahwa Lingkungan Keluarga merupakan salah satu faktor penting yang mempengaruhi Minat Berwirausaha. Minat berwirausaha akan terbentuk apabila keluarga memberikan pengaruh positif terhadap minat tersebut, karena sikap dan aktifitas sesama anggota keluarga saling mempengaruhi baik secara langsung maupun tidak langsung. Orang tua yang bekerja sebagai wiraswasta juga akan mempengaruhi pula pada pola pikir anak dalam menentukan pekerjaannya di masa yang akan datang, demikian juga pada minat berwiraswasta pada anak. Orang tua yang berwiraswasta dalam bidang tertentu dapat menimbulkan minat anaknya untuk berwirausaha dalam bidang yang sama pula.

4. Pengaruh Pendidikan Kewirausahaan, Ekspektasi Pendapatan, dan Lingkungan Keluarga terhadap Minat Berwirausaha (Studi Kasus Mahasiswa Program Studi Pendidikan Ekonomi STKIP Pembangunan Indonesia)

Hasil penelitian mendukung hipotesis keempat yang menunjukkan bahwa variabel Pendidikan Kewirausahaan $\left(\mathrm{X}_{1}\right)$, Ekspektasi Pendapatan $\left(\mathrm{X}_{2}\right)$ Lingkungan Keluarga $\left(\mathrm{X}_{3}\right)$ berpengaruh terhadap Minat Berwirausaha.

Minat berwirausaha dipengaruhi oleh pendidikan kewirausahaan. Pengetahuan yang di dapat selama kuliah terutama mata kuliah kewirausahaan dapat digunakan untuk berwirausaha. Dengan memperoleh pengetahuan tentang kewirausahaan yang memadai akan memperoleh pemahaman berwirausaha serta dapat mendorong seseorang untuk berwirausaha. Faktor lain yang juga mempengaruhi Minat Berwirausaha mahasiswa Pendidikan Ekonomi STKIP Pembangunan Indonesia adalah ekspektasi pendapatan karena dalam menentukan suatu pekerjaan tidak lepas dari pertimbangan gaji atau pendapatan yang akan diperolehnya. Menjadi seorang wirausaha tentunya menginginkan pendapatan yang lebih besar daripada menjadi pekerja, semakin tinggi harapan seseorang akan pendapatan yang dihasilkan dari berwirausaha maka akan semakin tinggi pula minat seseorang untuk berwirausaha, karena dengan berwirausaha dapat memiliki pendapatan yang tinggi tergantung dari usaha yang dilakukanya.

\section{SIMPULAN DAN SARAN Kesimpulan}

Berdasarkan data yang diperoleh dari hasil analisis yang dilakukan maka dapat disimpulkan sebagai berikut:

1. Terdapat pengaruh positif Pendidikan Kewirausahaan terhadap Minat Berwirausaha Mahasiswa Pendidikan Ekonomi STKIP Pembangunan Indonesia. Hal tersebut terbukti dari hasil t hitung variabel Pendidikan Kewirausahaan sebesar 2,718 dimana nilai tersebut lebih besar dari nilai $\mathrm{t}$ tabel yaitu 1,97253 dengan nilai signifikansi 0,047 lebih kecil dari 0,05. Semakin tinggi Pendidikan Kewirausahaan maka akan semakin tinggi pula Minat 
Berwirausaha Mahasiswa Pendidikan Ekonomi STKIP Pembangunan Indonesia.

2. Terdapat pengaruh positif Ekspektasi Pendapatan terhadap Minat Berwirausaha Mahasiswa Pendidikan Ekonomi STKIP Pembangunan Indonesia. Hal tersebut terbukti dari hasil $t$ hitung variabel Ekspektasi Pendapatan sebesar 4,103 dimana nilai tersebut lebih besar dari nilai $\mathrm{t}$ tabel yaitu 1,97253 dengan nilai signifikansi 0,022 lebih kecil dari 0,05 . Semakin tinggi Ekspektasi Pendapatan maka akan semakin tinggi pula Minat Berwirausaha Mahasiswa Pendidikan Ekonomi STKIP Pembangunan Indonesia.

3. Terdapat pengaruh positif Lingkungan Keluarga terhadap Minat Berwirausaha Mahasiswa Pendidikan Ekonomi STKIP Pembangunan Indonesia. Hal tersebut terbukti dari hasil $t$ hitung variabel Lingkungan Keluarga sebesar 6,937 dimana nilai tersebut lebih besar dari nilai $\mathrm{t}$ tabel yaitu 1,97253 dengan nilai signifikansi 0,022 lebih kecil dari 0,05. Semakin tinggi Lingkungan Keluarga maka akan semakin tinggi pula Minat Berwirausaha Mahasiswa Pendidikan Ekonomi STKIP Pembangunan Indonesia.

4. Terdapat pengaruh positif pendidikan kewirausahaan, Ekspektasi Pendapatan, dan Lingkungan Keluarga terhadap Minat Berwirausaha Mahasiswa Pendidikan Ekonomi STKIP Pembangunan Indonesia. Hal tersebut terlihat dari nilai signifikansi uji Anova (Uji F) yaitu sebesar 0,003 lebih kecil dari 0,05 . Semakin tinggi pendidikan kewirausahaan, Ekspektasi Pendapatan, dan Lingkungan Keluarga maka akan meningkatkan Minat Berwirausaha Mahasiswa Pendidikan Ekonomi STKIP Pembangunan Indonesia. Hasil penelitian ini yaitu Minat Berwirausaha Mahasiswa Program Studi Pendidikan Ekonomi STKIP Pembangunan Indonesia dijelaskan oleh variabel Pendidikan Kewirausahaan, Ekspektasi Pendapatan, dan Lingkungan Keluarga sebesar 32,2\%.

\section{Saran}

1. Bagi Mahasiswa Program Studi Pendidikan Ekonomi STKIP Pembangunan Indonesia sebelum perkuliahan sebaiknya benar-benar memahami silabus sehingga memudahkan dalam memahami materi Pendidikan Kewirausahaan yang diajarkan. Pernyataan mengenai komposisi materi yang disusun berdasarkan silabus dapat mempermudah mahasiswa memahami materi kuliah yang diajarkan memiliki rata-rata skor terendah pada butir pernyataan variabel Pendidikan.

2. Sebaiknya mahasiswa Mahasiswa Program Studi Pendidikan Ekonomi STKIP Pembangunan Indonesia lebih optimis dan berani mengambil risiko. Hal tersebut dapat dilihat dari rendahnya rata-rata skor yang diberikan responden untuk variabel Ekspektasi Pendapatan pada item pendapatan yang tidak terbatas dari berwirausaha. Mayoritas mahasiswa tidak optimis dan tidak percaya diri terhadap pendapatan yang dihasilkan dari berwirausaha. Anggapan pendapatan yang tidak pasti dalam berwirausaha sebaiknya dihilangkan karena jumlah pendapatan yang dihasilkan tergantung seberapa keras usaha yang dilakukan seseorang.

3. Pihak perguruan tinggi berperan dalam membentuk karakter wirausaha pada setiap mahasiswa, sehingga dalam diri individu terbentuk mental job creator bukan job seeker mengingat lapangan pekerjaan $\mathrm{di}$ sektor negeri dan swasta semakin terbatas. Melalui Pendidikan Kewirausahaan pihak perguruan tinggi dapat memberikan bekal dalam meningkatkan keterampilan berwirausaha. Oleh karena itu, pemberian bekal tersebut sebaiknya tidak hanya berupa teori saja, melainkan praktik secara berkelanjutan sehingga harapannya mahasiswa benar-benar dituntut untuk terjun secara langsung dalam kegiatan usaha.

4. Hasil penelitian ini yaitu Minar Berwirausaha Mahasiswa Program Studi Pendidikan Ekonomi STKIP Pembangunan Indonesia dijelaskan oleh variabel Pendidikan Kewirausahaan, Ekspektasi Pendapatan, dan Lingkungan Keluarga sebesar $32,2 \%$. Sehingga untuk penelitian selanjutnya dapat menambah variabel lain seperti keterampilan berwirausaha, kepribadian, norma subyektif, dan lain sebagainya.

\section{DAFTAR RUJUKAN}

Buchori Alma. (2011). Kewirausahaan. Bandung: Alfabeta.

Firlian, E. 2018. "Pengaruh Pendidikan Kewirausahaan, Sikap, Lingkungan Keluarga, dan Motivasi Terhadap 
Minat Berwirausaha (Studi Kasus pada Mahasiswa Aktif Fakultas Ekonomi Universitas Islam Indonesia yang Memiliki Usaha Pribadi)". Skripsi: Universitas Islam Indonesia

Ghozali, I. (2011). Aplikasi Analisis Multivariate dengan Program IBM SPSS 19 Edisi 5. Semarang: Badan Penerbit Universitas Diponegoro.

Indarti; Nurul. (2008). Intensi Kewirausahaan Mahasiswa: Studi Perbandingan antara Indonesia, Jepang dan Norwegia. Jurnal Ekonomika dan Bisnis Indonesia Volume 23 No 04 , 1-27.

Kasmir. (2011). Kewirausahaan. Jakarta: PT. Raja Grafindo Persada Retno Budi

Paulus Patria Adhitama. (2014). "Faktor-Faktor yang Mempengaruhi Minat Berwirausaha (Studi Kasus Mahasiswa Fakultas Ekonomika dan Bisnis UNDIP, Semarang). Skripsi. UNDIP.

Soemanto, Wasty.2008, Pendidikan Wiraswasta, Jakarta : Bumi Aksara

Sugiyono. (2011). Metode Penelitian Kombinasi (Mix Methode). Bandung: CV. Alfabeta.

Zimmerer, Thomas W., dkk. (2008). Kewirausahaan dan Manajemen Usaha Kecil. Jakarta: Salemba Empat 